\title{
Corydoras tukano, a new species of corydoradine catfish from the rio Tiquié, upper rio Negro basin, Brazil (Ostariophysi: Siluriformes: Callichthyidae)
}

\author{
Marcelo R. Britto* and Flávio C.T. Lima**
}

A new Corydoras species from the rio Tiquié, upper rio Negro system, Amazonas, Brazil, is described. This taxon was previously referred to as "Corydoras species "Asher", "Corydoras cf. reynoldsi", and "Corydoras aff. reynoldsi" in the aquarist literature. The new taxon can be distinguished from all its congeners, except Corydoras reynoldsi and C. weitzmani, by its color pattern, consisting of three large, dark blotches, the first one ("mask") on the head, across the eye; the second one on the trunk at the level of dorsal fin; and the third one on the trunk at the level of the adipose fin. It can be distinguished from Corydoras reynoldsi mainly by the development of trunk blotches; and from C. weitzmani by the presence of a dusky saddle between the dorsal and adipose fins, the second trunk blotch extending vertically from the adipose-fin base to the anal-fin base, and the presence of four dark stripes in the caudal fin.

Uma nova espécie de Corydoras do rio Tiquié, bacia do alto rio Negro, estado do Amazonas, Brasil, é descrita. Este táxon foi anteriormente citado na literatura aquarista como "Corydoras species "Asher", "Corydoras cf. reynoldsi" e "Corydoras aff. reynoldsi". O novo táxon pode ser distinguido de todos seus congêneres, exceto Corydoras reynoldsi e $C$. weitzmani, por seu padrão de colorido, que consiste em três grandes manchas pretas, a primeira ("máscara") na cabeça, através do olho; a segunda no tronco, no nível da nadadeira dorsal; e a terceira no tronco, no nível da nadadeira adiposa. Ele pode ser distinguido de Corydoras reynoldsi principalmente pelo desenvolvimento das manchas do tronco, e de C. weitzmani pela presença de uma mancha escura na porção dorsal das placas dorsolaterais, entre a nadadeira dorsal e a nadadeira adiposa, pela segunda mancha estender-se verticalmente da base da nadadeira adiposa até a base da nadadeira anal, e pela presença de quatro listras pretas na nadadeira caudal.

Key words: Corydoras reynoldsi, Corydoras weitzmani, Neotropical, Amazon.

\section{Introduction}

Corydoras Lacepède is one of the most speciose catfish genera, currently comprising 176 nominal species, of which 143 species are presently considered valid (Reis, 2003). The genus is widely distributed in Cis-andean South America, occurring in a variety of habitats, such as shallow, marginal areas of rivers and associated flooded areas, and smaller streams. Despite several significant contributions during the course of the extensive taxonomic history of Corydoras (e.g. Gosline, 1940; Nijssen, 1970; Nijssen \& Isbrücker, 1980, 1983a, 1986), and recent attempts to define its limits (Reis,
1998; Britto \& Castro, 2002), the status of most species as well as their phylogenetic relationships are still poorly understood.

During two recent ichthyological surveys in the rio Tiquié, a tributary of the rio Uaupés, in the upper Rio Negro system in Estado do Amazonas, Brazil, one of the authors (FCTL) collected an unusual corydoradine catfish, which resembled Corydoras reynoldsi Myers \& Weitzman in its color pattern. We found later that this taxon was previously referred to in the aquarist literature as "Corydoras species 'Asher", "Corydoras cf. reynoldsi", and "Corydoras aff. reynoldsi" (Anonymous, 1998; Finley, 1998; Lucanus, 1998). Comparisons

\footnotetext{
* Departamento de Vertebrados, Museu Nacional da Universidade Federal do Rio de Janeiro, Quinta da Boa Vista, 20940-040 Rio de Janeiro, RJ, Brazil. e-mail: mrbritto2002@yahoo.com.br

** Museu de Zoologia da Universidade de São Paulo, Caixa Postal 42594, 04299-970 São Paulo, SP, Brazil. e-mail: fctlima@usp.br
} 


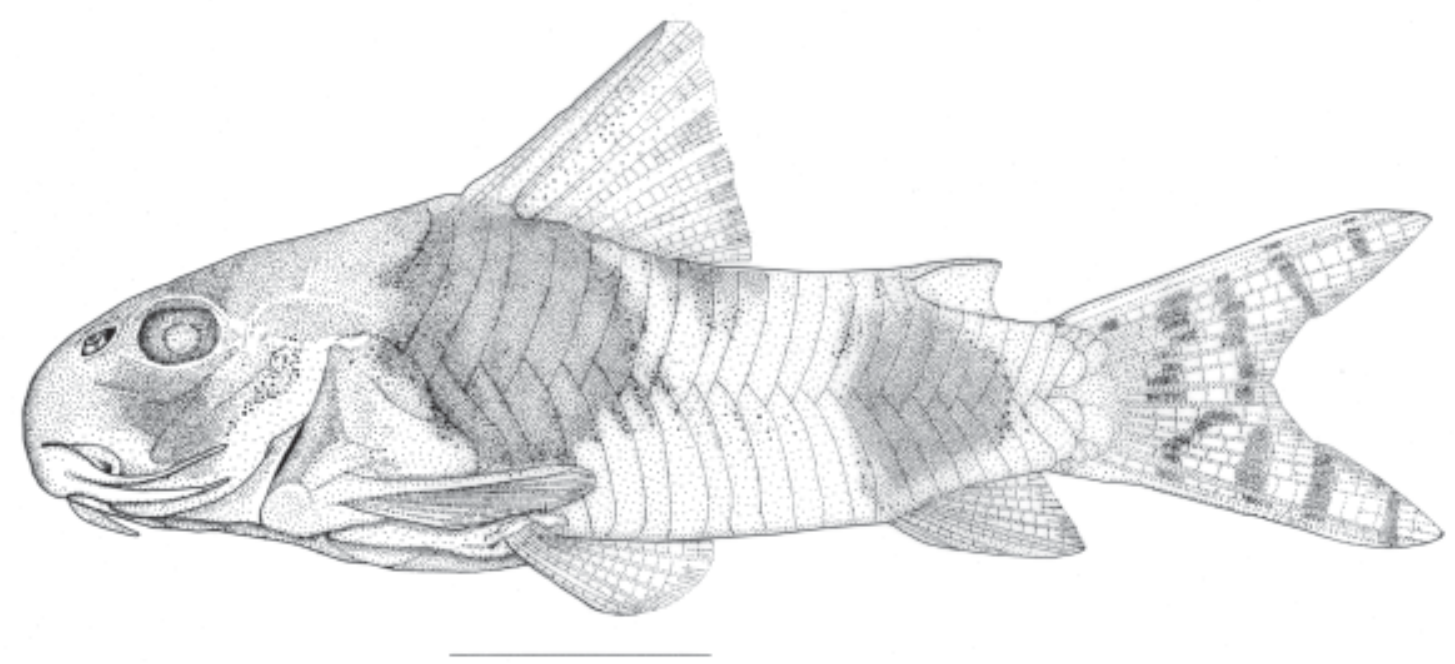

Fig. 1. Corydoras tukano, holotype, MZUSP 82100, presumably a female, $40.9 \mathrm{~mm}$ SL; Brazil, Amazonas state, rio Tiquié, comunidade de Caruru. Caudal-fin margin reconstructed from MZUSP 81194, 37.4 mm SL.

between the material collected in the rio Tiquié and paratypes of Corydoras reynoldsi revealed that it is, in fact, a distinct species, that is described below.

\section{Material and Methods}

Morphometric and meristic data were taken following Reis (1997). Length of the ossified portion of pectoral spine was measured from the spine-pectoral girdle articulation to distal tip of spine. Length of the soft portion of the dorsal fin was taken from the dorsal spine base to the fin distalmost tip. Measurements were obtained with $0.1 \mathrm{~mm}$ precision calipers. Teeth and vertebral counts were taken only from clearedand-stained (cs) specimens, prepared according to Taylor \& Van Dyke (1985). Vertebral counts include only free centra, with the compound caudal centra (preural $1+$ ural 1) counted as a single element. In the description, numbers assigned with an asterisk represent counts from the holotype. Nomenclature of latero-sensory canals follows Schaefer \& Aquino (2000), and that of preopercular pores follows Schaefer (1988). Osteological terminology follows Reis (1998), except by "parieto-supraoccipital" instead of "supraoccipital" (Arratia \& Gayet, 1995), "compound pterotic" instead of "pteroticsupracleithrum" (Aquino \& Schaefer, 2002), and "scapulocoracoid" instead of "coracoid" (Lundberg, 1970). In the present study, the term "maxillary barbel" (previously named "upper maxillary barbel" or "dorsal maxillary barbel"; e.g. Britto et al., 2002) refers only to the sensorial structure with its core linked to the maxilla. The so-called "ventral maxillary barbel" or "rictal barbel" has its core extended to the dentary symphysis, corresponding, in fact, to a modified mental barbel (Baskin, 1973; de Pinna, 1998). Thus, this structure is named herein as "outer mental barbel", differing from the inner one. The term "Corydoras" refers to those species closer to Aspidoras than to Brochis, as briefly explained in Britto \& Castro (2002). Institutional abbreviations are: ANSP, Academy of Natural Sciences, Philadelphia; CAS, California Academy of Sciences, San Francisco; CAS-SU, former Stanford University, now at CAS; INPA, Instituto Nacional de Pesquisas da Amazônia, Manaus; MNRJ, Museu Nacional da Universidade Federal do Rio de Janeiro; and MZUSP, Museu de Zoologia da Universidade de São Paulo, São Paulo.

A list of the comparative material is available in Britto \& Castro (2002). In addition, the following material was studied: Corydoras adolfoi MZUSP 22641, holotype; C. boehlkei MZUSP 77809 (6); C. davidsandsi MZUSP 38633-38635 (3), paratypes; C. incolicana MZUSP 45717, holotype; $C$. $c f$. melini MZUSP 65688 (1); MZUSP 81163 (2); C. parallelus MZUSP 45716, holotype; C. reynoldsi CAS-SU 50702 (2), paratypes; C. robineae MZUSP 27175, holotype; MZUSP 27176-21777 (2), paratypes; MZUSP 81130 (2); Corydoras sp. "mimic" MZUSP 82344 (1).

\section{Corydoras tukano, new species}

Figs. 1-4

Holotype. MZUSP 82100 (40.9 mm SL), Brazil, estado do Amazonas, rio Tiquié, comunidade de Caruru, beaches in pool below the fall, 0¹6'28.9"N, 6954'53.6"W (UTM 19N0398191/ 0030366); Flávio C.T. Lima et al., 20-21 Oct 2002.

Paratypes. All from Brazil, estado do Amazonas: MZUSP 81194 (5, 34.5-40.3 mm SL); CAS 217960 (1, $34.6 \mathrm{~mm} \mathrm{SL})$; same data as holotype. MZUSP 64096 (4, 28.2-38.0 mm SL), rio Tiquié, comunidade de Boca do Sal; Rafael, 23 Oct 2000. MZUSP 65689 (2, 33.2-38.5 mm SL); ANSP 179201 (1,35.8 mm $\mathrm{SL})$; rio Tiquié, one hour by boat below comunidade de Cunuri, below Cachoeira do Tucano, $0^{\circ} 12^{\prime} 23^{\prime \prime} \mathrm{N}, 69^{\circ} 22^{\prime} 28^{\prime \prime} \mathrm{W}$ (UTM 19N458666/22437; coordinates are from Cunuri); M. L. Lopes, 29 Nov 2000. MZUSP 81179 (2, 34.0-36.1 mm SL), rio Tiquié, 


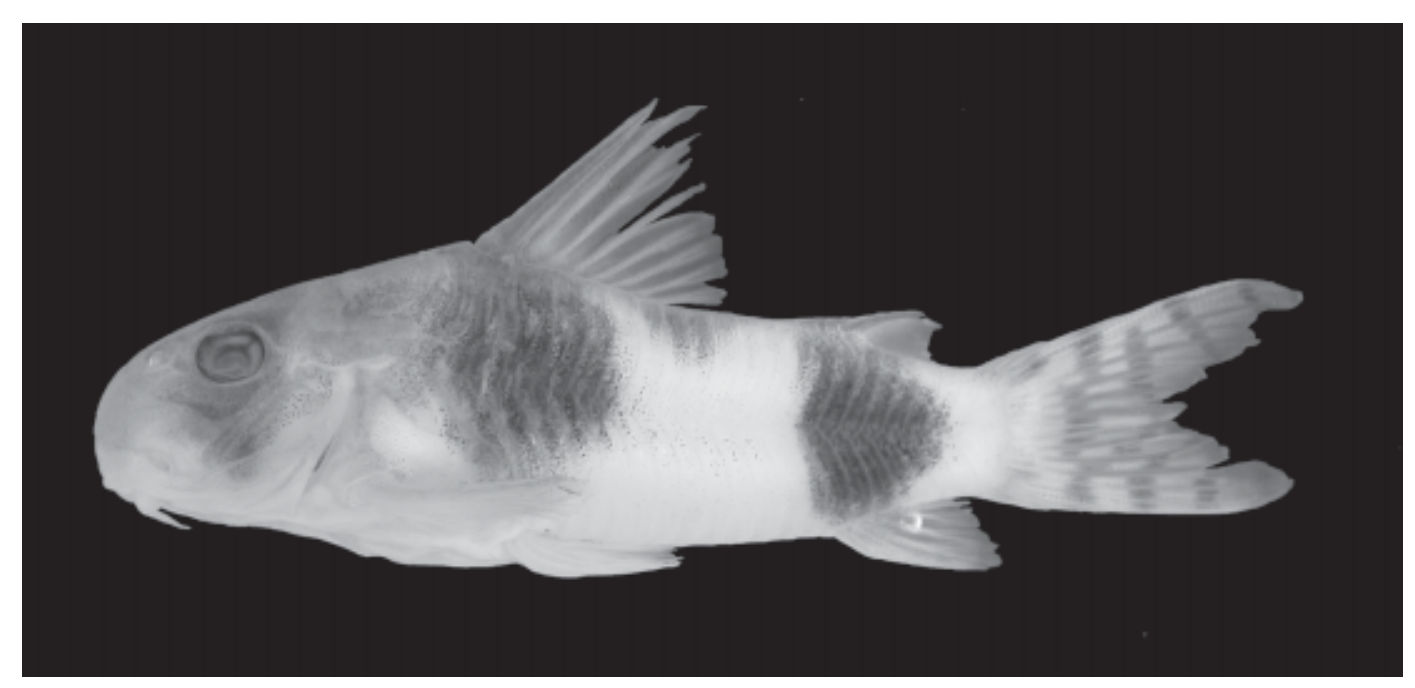

Fig. 2. Corydoras tukano, holotype, MZUSP 82100, presumably a female, $40.9 \mathrm{~mm}$ SL; Brazil, estado do Amazonas, rio Tiquié, comunidade de Caruru.

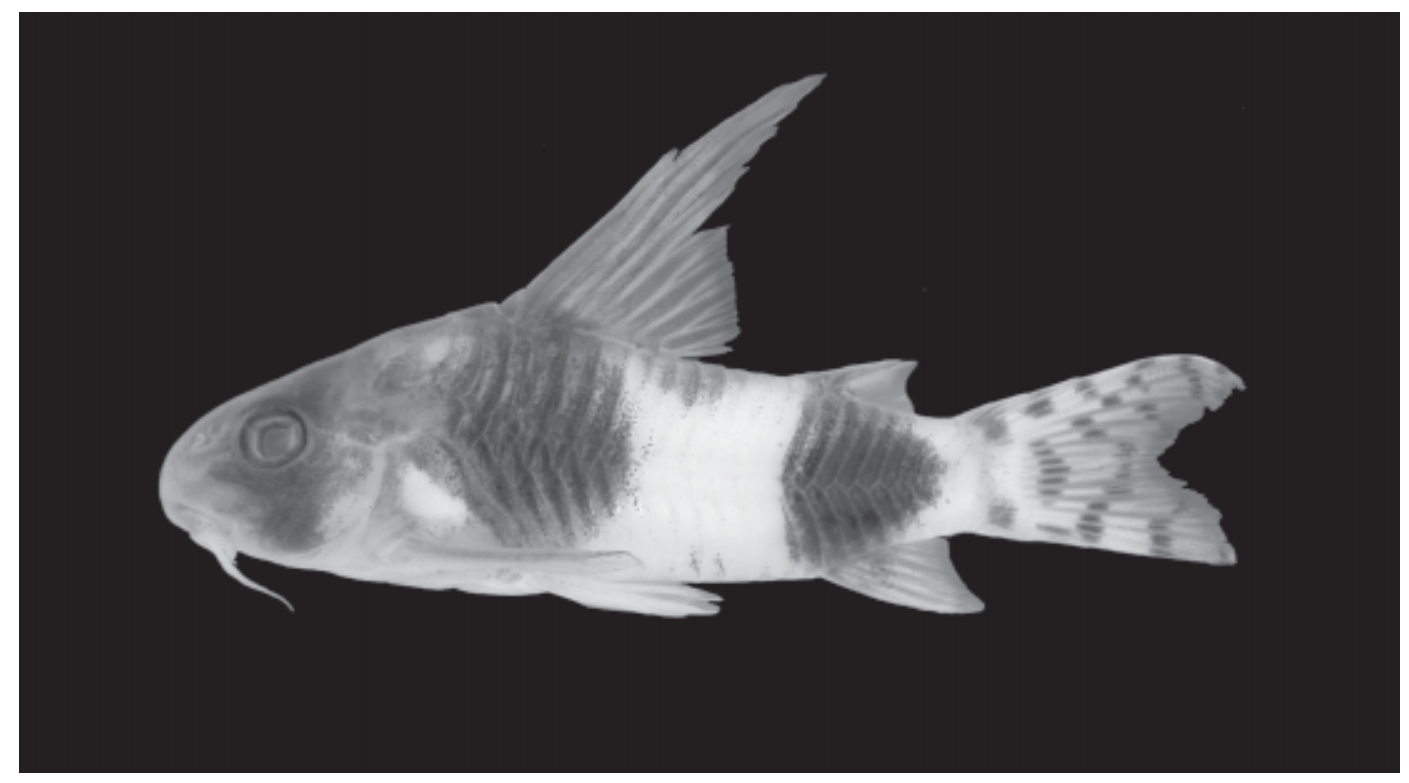

Fig. 3. Corydoras tukano, paratype, MZUSP 81179, presumably a mature male, $36.1 \mathrm{~mm}$ SL; Brazil, estado do Amazonas, rio Tiquié, comunidade de Boca do Sal.

comunidade de Boca do Sal, 0¹6'22.5” N, 6954'03” W (UTM 19N0399757/0030167); N. P. Marques, 25 Oct 2002. MZUSP 81244 (16, 20.3-41.4 mm SL); INPA 21423 (2, 25.6-36.0 mm SL); MNRJ 25355 (2, 24.4-32.0 mm SL); igarapé Cabari, comunidade de Coração de Maria, 0¹6'59.2” N, 6950'04.2” W (UTM 19N0407140/0031302); Tarcísio \& N. P. Marques, 29 Oct 2002. MZUSP $81276(5,19.9-26.2 \mathrm{~mm} \mathrm{SL})$, rio Tiquié, comunidade de Boca do Sal, 0¹6'22.5” N, 6954'03”'W (UTM 19N0399757/ 0030167); F. C. T. Lima et al., 7 Nov 2002. MZUSP 81153 (9, 35.4-37.2 mm SL, 6 cs, 20.9-38.3 mm SL), rio Tiquié, between the comunidades de Caruru and Boca de Sal, $0^{\circ} 16^{\prime} \mathrm{N}, 69^{\circ} 54^{\prime} \mathrm{W}$; M. L. Lopes et al., 2001-2002. MZUSP 81216 (2, 17.1-21.3 mm $\mathrm{SL}$ ), rio Tiquié, between the comunidades de São Domingos Sávio and Jabuti, 0¹5-16’ N, 6951-54’W; F.C.T. Lima et al., 7 Nov 2002.
Diagnosis. Corydoras tukano can be distinguished from all its congeners, except $C$. reynoldsi Myers \& Weitzman and $C$. weitzmani Nijssen, by its color pattern consisting of a light ground coloration, with three dark, large, roughly rectangular blotches: the first one ("mask") on the head, across the eye; the second one on the trunk at the level of dorsal fin; and the third one on the trunk at the level of the adipose fin. It can be distinguished from $C$. reynoldsi by the larger dark blotches, which in $C$. tukano are broad, with the trunk blotches extending across 5-6 series of lateral plates. In $C$. reynoldsi, the first trunk blotch (i.e., at the level of dorsal fin), is a discrete, verticallyelongated bar, and the second trunk blotch extends only across 2-3 series of lateral plates (see Myers \& Weitzman, 1960: fig. 2; Nijssen \& Isbrücker, 1983a: fig.10). See "Discussion" for additional evidence for the recognition of both as distinct species. 


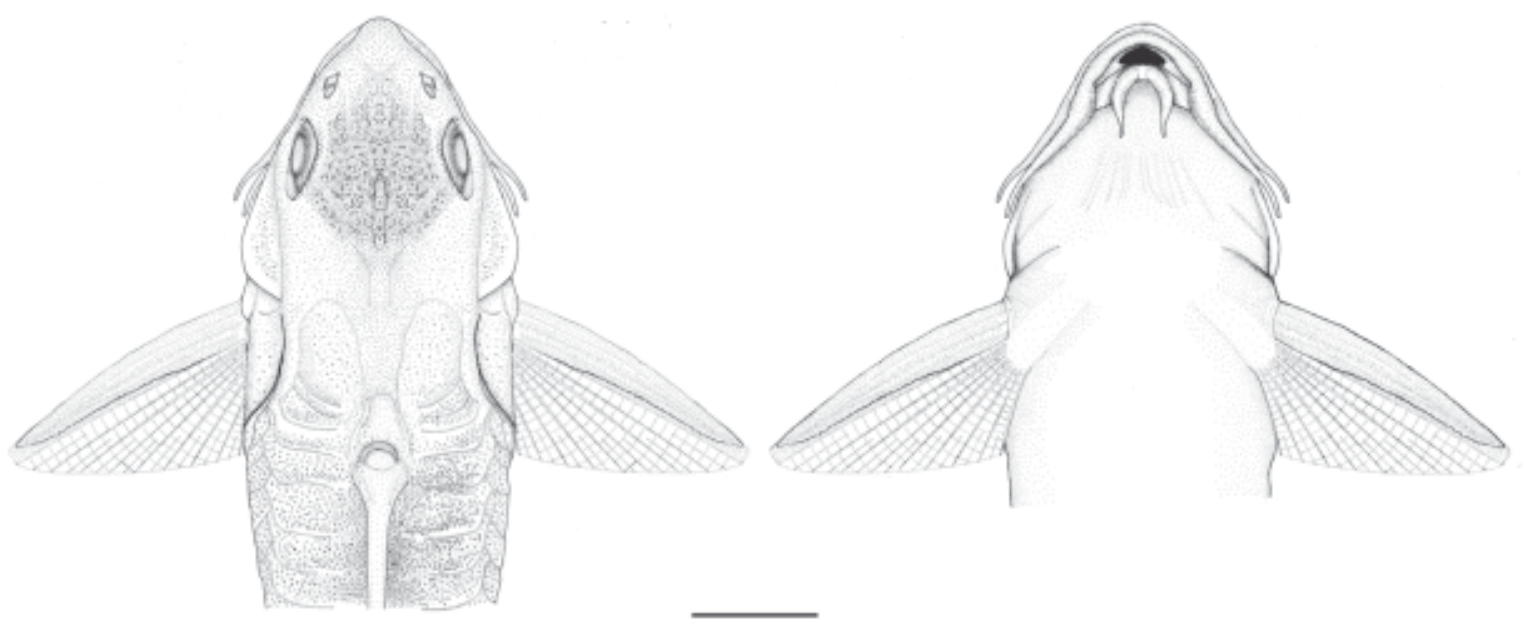

Fig. 4. Dorsal (left) and ventral (right) views of head and pectoral fins of Corydoras tukano, holotype, MZUSP 82100, 40.9 mm SL; Brazil, estado do Amazonas, rio Tiquié, comunidade de Caruru.

Corydoras tukano may be distinguished from $C$. weitzmani by the presence of a dark blotch or saddle on the dorsal portion of dorsolateral plates, just posterior to last dorsal-fin ray, that extends from the 9th to the 13th plate ( $v s$. absent); by the second trunk blotch extending vertically from

Table 1. Morphometric data of the holotype and paratypes of Corydoras tukano (ANSP 179201, $\mathrm{n}=1$; CAS 217960, $\mathrm{n}=1$; INPA 21423, $\mathrm{n}=2$; MNRJ 25355, $\mathrm{n}=1$; MZUSP 64096, $\mathrm{n}=4$; MZUSP 65689, $\mathrm{n}=3$; MZUSP 81179, $\mathrm{n}=2$; MZUSP 81194, $\mathrm{n}$ = 5; MZUSP 81244, $\mathrm{n}=9$; MZUSP 81276, $\mathrm{n}=2$; MZUSP $81153, \mathrm{n}=3)$. $\mathrm{SD}=$ Standard deviation.

\begin{tabular}{|c|c|c|c|c|c|}
\hline & Holotype & $\mathrm{n}$ & Min.-Max. & Mean & SD \\
\hline Standard length (mm) & 40.9 & 33 & $21.2-41.4$ & - & - \\
\hline \multicolumn{6}{|l|}{$\begin{array}{l}\text { Percents of standard } \\
\text { length }\end{array}$} \\
\hline Depth of body & 33.5 & 33 & $28.9-35.8$ & 32.7 & 1.70 \\
\hline Predorsal distance & 45.2 & 33 & $37.6-46.6$ & 43.6 & 2.35 \\
\hline Prepelvic distance & 46.2 & 33 & $36.5-48.6$ & 45.7 & 2.14 \\
\hline Preanal distance & 81.7 & 33 & $73.8-83.9$ & 80.7 & 1.98 \\
\hline Preadipose distance & 84.6 & 33 & $76.6-85.5$ & 82.1 & 2.39 \\
\hline Length of dorsal spine & 25.2 & 33 & $24.5-31.1$ & 27.4 & 5.28 \\
\hline \multicolumn{6}{|l|}{$\begin{array}{l}\text { Length of longest soft } \\
\text { dorsal fin ray }\end{array}$} \\
\hline Mature males & - & 3 & $42.1-48.5$ & 45.3 & 3.20 \\
\hline $\begin{array}{l}\text { Females and/or immature } \\
\text { males }\end{array}$ & 27.4 & 26 & $23.6-36.5$ & 30.6 & 2.91 \\
\hline Length of pectoral fin spine & 29.3 & 33 & $24.8-33.2$ & 27.9 & 2.17 \\
\hline Length of adipose fin spine & 8.3 & 33 & $7.7-11.8$ & 9.7 & 1.43 \\
\hline Depth of caudal pedncle & 13.2 & 33 & $12.4-14.4$ & 13.3 & 5.17 \\
\hline Dorsal to adipose distance & 23.5 & 33 & $19.6-24.9$ & 22.1 & 1.49 \\
\hline Length of dorsal fin base & 20.5 & 33 & $17.9-25.9$ & 20.9 & 4.14 \\
\hline Maximum cleithral width & 24.4 & 33 & $21.1-26.8$ & 24.7 & 1.64 \\
\hline Head length & 39.6 & 33 & $34.0-41.3$ & 38.8 & 1.46 \\
\hline Length of maxillary barbel & 13.4 & 32 & $10.3-18.7$ & 14.3 & 1.93 \\
\hline \multicolumn{6}{|l|}{ Percents of head length } \\
\hline Head depth & 69.8 & 33 & $54.5-72.3$ & 67.4 & 3.97 \\
\hline Least interorbital distance & 25.9 & 33 & $23.4-32.2$ & 28.0 & 2.36 \\
\hline Horizontal orbit diameter & 18.5 & 33 & $17.3-24.1$ & 20.3 & 1.82 \\
\hline Snout length & 36.4 & 33 & $27.2-37.5$ & 33.2 & 2.31 \\
\hline Least internareal distance & 16.0 & 33 & $13.3-21.3$ & 17.4 & 1.83 \\
\hline
\end{tabular}

adipose- to anal-fin base and along ventral surface of ventrolateral body plates ( $v s$. reaching neither anal-fin base nor ventral surface of ventrolateral body plates); and by the presence of four dark, vertical stripes, in the caudal fin ( $v s$. stripes absent) (see Nijssen, 1971: fig. 1; Nijssen \& Isbrücker, 1986: fig. 27; Burgess, 1989: plate 180).

Description. Morphometric data presented in Table 1. Head compressed with slightly convex dorsal profile; roughly triangular in dorsal view (Fig. 4). Snout rounded. Head profile convex from upper lip to horizontal through the anterior nares; slightly convex from that point to tip of parieto-supraoccipital expansion. Dorsal profile of body slightly convex from tip of parieto-supraoccipital expansion to last dorsal-fin ray. Postdorsal-fin body profile slightly concave to adipose-fin spine; markedly concave from this point to caudal-fin base. Ventral profile of body slightly convex from isthmus to analfin origin. Profile markedly concave from first anal-fin ray to caudal-fin base. Body roughly cylindrical in cross section at pectoral girdle, gradually becoming more compressed toward caudal fin.

Eye round, located dorso-laterally on head; orbit delimited dorsally by frontal and sphenotic, ventrally by infraorbitals. Anterior and posterior nares proximal, only separated by flap of skin. Anterior naris tubular. Posterior naris close to anterodorsal margin of orbit, separated from it by distance equal to naris diameter. Mouth small, subterminal, width nearly equal to bony orbit diameter. Maxillary barbel elongate, usually reaching anteroventral limit of gill opening (Fig. 4). Maxillary barbel slightly longer than outer mental barbel. Inner mental barbel fleshy. Right inner mental barbel forked in one specimen (MZUSP 81194, $38.0 \mathrm{~mm}$ SL). Small rounded papillae covering entire surface of all barbels, upper and lower lips, and isthmus. Gill membranes united to isthmus. Four branchiostegal rays covered by thick layer of skin; distal two rays united at their tips by branchiostegal cartilage. Teeth on upper pharyngeal tooth plate 32 (2), 39 (1), 52 (1), 53 (1), or 54 
(1), and on fifth ceratobranchial 32 (1), 35 (1), 42 (1), 46 (1), 49 (1), or 50 (1), increasing in number during ontogeny.

Nasal, frontal, sphenotic, compound pterotic, and parietosupraoccipital visible externally, all covered by thin layer of skin and bearing minute scattered odontodes. Frontal fontanel elongate, ellipsoid, covered by thin layer of skin; posterior tip extending into parieto-supraoccipital. Nasal slender, slightly curved laterally, mesial border contacting frontal. Frontal quadrangular; anterior expansion in contact with nasal bone, posterior portion contacting sphenotic and parietosupraoccipital. Sphenotic trapezoid in shape, contacting parieto-supraoccipital dorsally, compound pterotic posteriorly, second infraorbital ventrally. Compound pterotic roughly pipe-shaped, with slender posterior expansion contacting first dorsal body plate and first lateral-line ossicle. Contact region between compound pterotic and first dorsal body plate covered by area of thick skin. Ventral margin of compound pterotic contacting infraorbital 2 and cleithrum. Parietosupraoccipital quadrangular with posterior expansion notched at its tip, sutured with nuchal plate.

Two infraorbital bones, externally visible, covered by thin layer of skin. First infraorbital with slender anterior expansion. Minute odontodes-bearing platelets anterodorsally on orbit (Fig. 5). Presence of small, narrow, roughly triangular platelet between eye and anterior expansion of first infraorbital (Fig. 5). Opercle exposed, compact in shape, with angular free border. Preopercle externally visible, slender and covered by thin layer of skin. Interopercle triangular, covered by thin layer of skin.

Trunk lateral line with two laterosensory canals, reduced to small ossicles. Lateral-line canal entering neurocranium through compound pterotic, splitting into two branches before entering sphenotic: pterotic and preoperculomandibular, each with single pore. Sensory canal continuing through compound pterotic, entering sphenotic as temporal canal, which splits into two branches: one branch giving rise to infraorbital canal, other branch entering frontal through supraorbital canal. Supraorbital canal with two branches: epiphyseal, opening in frontal bone, and anterior, running through nasal bone. Nasal canal with single opening at each end. Infraorbital canal running through entire second infraorbital, extending to infraorbital 1 and opening into two pores. Preoperculomandibular branch giving rise to preoperculomandibular canal, which runs through entire preopercle with three openings, leading to pores 3,4 , and 5, respectively.

Body plates with minute odontodes restricted to posterior margins. Nuchal plate exposed. Cleithrum and mesial process of scapulocoracoid exposed. Minute odontodes scattered over area between scapulocoracoids. Body plates not touching counterparts in specimens up to $28.2 \mathrm{~mm} \mathrm{SL}$, leaving narrow naked area on medial dorsal and ventral surfaces. Dorsolateral body plates $23(11), 24 *(21)$, or 25 (1); ventrolateral body plates 20 (2), 21* (29), or 22 (2); dorsolateral body plates along dorsal-fin base $6(12), 7^{*}(20)$, or 8 (1); dorsolateral body plates from adipose fin to caudal-fin base 7 (13) or $8^{*}$

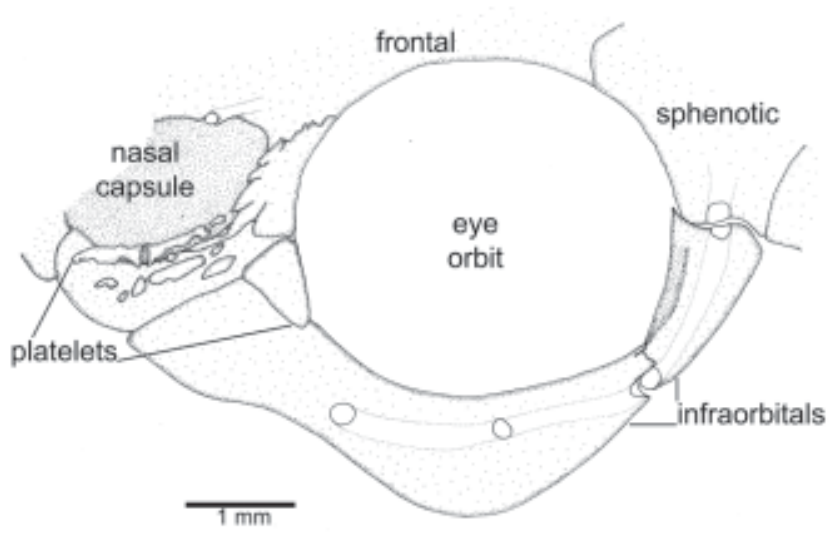

Fig. 5. Orbital region of Corydoras tukano, paratype, MZUSP 81153, showing odontode-bearing platelets around the eye. Odontodes not depicted.

(20); preadipose platelets $2(4), 3 *(8), 4(18)$, or 5 (3). Precaudal vertebrae 8 (3), 9 (3); caudal vertebrae 13 (1), 14 (3), 15 (2); five pairs of ribs, first pair conspicuously larger than others.

Dorsal fin roughly triangular; its origin just posterior to third dorsolateral body plate. Dorsal spine shorter than 1 st or 2nd branched rays. Distal tip of spine with minute-segmented unossified portion. Anterior border of dorsal spine smooth; posterior border with minute serrations. First two branched dorsal-fin rays and unossified portion of dorsal spine markedly elongate in large males; first branched ray the longest (see Fig. 3 and "Sexual dimorphism", below). Dorsal-fin rays I,7 in all specimens examined. Adipose fin roughly triangular; its origin separated from base of last dorsal-fin ray by 7-9 dorsolateral body plates. Anal fin roughly triangular; its origin located just posterior to 13th to14th ventrolateral body plates, at vertical through anterior margin of adipose-fin spine. Analfin rays ii,5 in all specimens. Pectoral fin triangular; its origin located just posterior to gill opening. Ossified portion of pectoral spine shorter than first branched rays. Distal tip of spine with minute-segmented unossified portion. Pectoral spine with well-developed serrations along entire posterior border. Pectoral-fin rays I,8, one specimen with I,7. Pelvic fin ellipsoid; its origin just below second ventrolateral body plate, at vertical through base of second branched dorsal-fin ray. Pelvic-fin rays i,5. Caudal fin bilobed; upper lobe slightly longer. Principal caudal-fin rays i,6/6,i, one specimen i,7/6,i; upper procurrent caudal-fin rays iii; lower procurrent caudalfin rays iii. All fins with minute odontodes scattered over all rays.

Color in alcohol. Ground coloration of head gray to brown, light ventrally. Wide, slightly oblique dark vertical blotch ("mask") from top of head throughout anterior and posterior margins of eye to lower anterior opercle corner. Dark v-shaped stripe between nares, with angle directed anteriorly. Barbels cream. Opercle and preopercle with narrow, dark, oblique, 
vertically-elongated blotch, formed by relatively large chromatophores.

Ground color of trunk cream to light brown. Nuchal plate gray to dark brown. Large, roughly rectangular, dorsolateral dark blotch ("first trunk blotch") extending dorsally from posterior margin of second plate to fifth-eighth dorsal plate, and ventrally from posterior margin of cleithrum to fifth ventral plate. Dark blotch on dorsal portion of dorsolateral plates, just posterior to last dorsal-fin ray, extending from 9 th to 13 th plate; in some specimens connected to large, anterior dorsolateral blotch. Second large, roughly rectangular, dorsolateral dark blotch ("second trunk blotch") below adipose fin, extending vertically from adipose- to anal-fin base. Scattered chromatophores on margins of plates, close to midline, between the two large dorsolateral blotches. Caudal fin with four vertical, narrow dark stripes. Dorsal- and pectoral-fin spines gray; remaining rays and membrane of both fins unpigmented. Base of anterior anal-fin rays dark, remaining rays and membrane unpigmented.

Color in life. Based on photographs published by Lucanus (1998: 14), Finley (1998: 129), Anonymous (1998: 210), and on field observations by FCTL. Very similar to preserved specimens, but ground color cream, never light brown; greenish metallic hue on opercle and cleithrum.

Sexual dimorphism. We have not dissected any specimens to confirm their sex, but aquarists who have bred the species in captivity (e.g. James, 2003a, b) mentioned that specimens with elongated dorsal fins are mature males. Presumably mature males examined (MZUSP 64096, 1 of 4; MZUSP 81179, 2) possess the soft portion of the dorsal spine, and the first two dorsal-fin branched rays very elongate. The first branched ray is the longest, followed by the soft portion of the dorsal spine. This results in an anteriorly elongated dorsal fin (see Fig. 3; Table 1). See the "Discussion", for comparisons with another Corydoras that possess elongated dorsal fins.

Popular name. "Waipotá" (both in Tukano and Tuyuka languages).

Habitat and ecological notes. The rio Tiquié, type-locality of C. tukano, is a blackwater river. At the exact type locality the bottom is sandy, with a moderate amount of vegetal debris. Corydoras tukano also was collected at sites with predominantly clay substrates. James $(2003 a, b)$ related that in captivity specimens of this species (identified by him as Corydoras sp. cf. reynoldsi) lay several scattered clutches of large eggs ( $2.2 \mathrm{~mm}$ in size). See also "Discussion", below.

Distribution. Known only from the rio Tiquié and its tributaries, as the igarapé Cabari. Rio Tiquié is a tributary of the rio Uaupés, in the upper rio Negro basin, Amazonas, Brazil, near the Brazilian/Colombian border (Fig. 6). Most of the specimens studied were collected in the upper rio Tiquié, in the area between Pari-Cachoeira $\left(0^{\circ} 15^{\prime} \mathrm{N}, 69^{\circ} 46^{\prime} \mathrm{W}\right)$ and

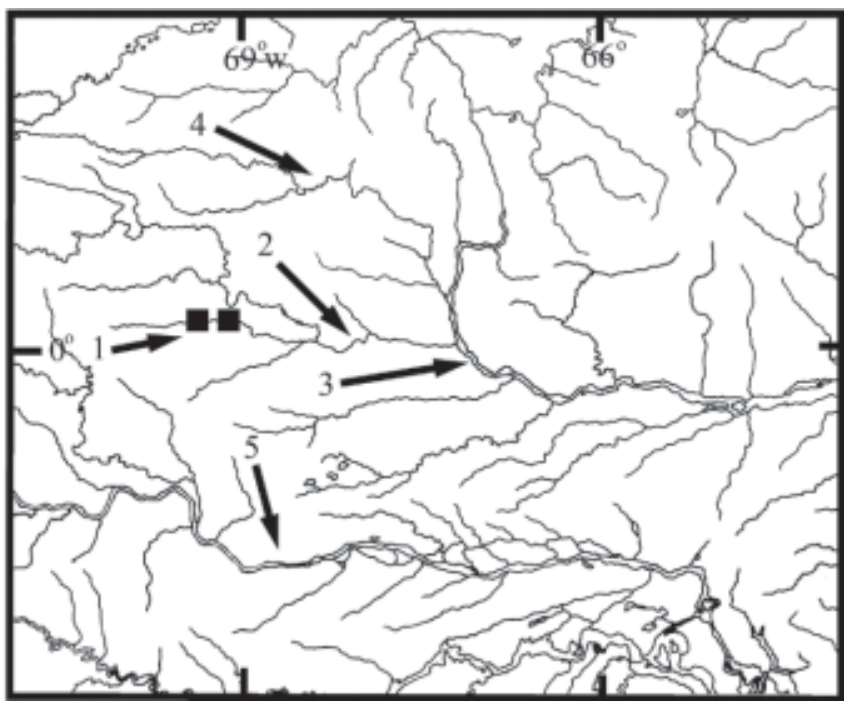

Fig. 6. Upper rio Negro basin and adjoining river basins, showing the distribution of Corydoras tukano (squares). 1Type locality, rio Tiquié; 2- rio Uaupés; 3 - rio Negro; 4- rio Içana; and 5 - rio Japurá.

Caruru $\left(0^{\circ} 16^{\prime} \mathrm{N}, 69^{\circ} 54^{\prime} \mathrm{W}\right)$. One sample (MZUSP 65689$)$ was collected near Cunuri $\left(0^{\circ} 12^{\prime} \mathrm{N}, 69^{\circ} 22^{\prime} \mathrm{W}\right)$, a downstream locality not intensively sampled by the second author or associates. According to Tukano and Tuyuka fishermen, Corydoras tukano occurs thorough the rio Tiquié basin, from its lower course upstream to Caruru, where a major waterfall about $8 \mathrm{~m}$ high, the Cachoeira do Caruru, effectively separates the downstream ichthyofauna from the upper section of this river. Again according to Tukano and Tuyuka fishermen, $C$. tukano is absent upstream of this waterfall. In fact, despite considerable time and effort spent in apparently suitable sites, the second author was unable to collect any C. tukano upstream of the Cachoeira do Caruru.

Etymology. After the Tukano, an Amerindian group from the upper rio Negro and Japurá/Caquetá basins in Brazil, Colombia, and Venezuela. Main cultural features displayed by this ethnic group are the Tukanoan language, the patrilineal clans system, and a diet having as staple foods manioc and fish (Chernella, 1989; Ribeiro, 1995). The presently known range of $C$. tukano is entirely within the Tukano territory.

\section{Discussion}

As noted above, Corydoras tukano recently appeared in the aquarist hobby tentatively identified as $C$. reynoldsi (Finley, 1998; Lucanus, 1998; James, 2003a,b). Both Finley (1998) and James (2003a,b) expressed doubts concerning the assignment of specimens of this species as $C$. reynoldsi. They correctly noticed differences in color pattern, which are detailed in the "Diagnosis", above. James (2003a) remarked that C. tukano (Corydoras sp. cf. reynoldsi of that author) differs from $C$. reynoldsi by the sexually dimorphic, elongate 
dorsal fin, and in the breeding biology in aquarium. According to him, $C$. reynoldsi deposited a mass of eggs, while $C$. tukano deposited several scattered small batches of eggs. Whether or not that author had correctly identified $C$. reynoldsi is something that cannot be verified.

Comparisons between $C$. tukano and two paratypes of $C$. reynoldsi (CAS-SU 50702) revealed an interesting feature concerning the development of body plates. In C. tukano, specimens up to $28.2 \mathrm{~mm}$ SL (MZUSP 64069) had the body plates not yet fully formed, leaving naked areas in both the medial dorsal and ventral regions, while in C. reynoldsi, specimens as small as $22.3 \mathrm{~mm}$ SL already have the body plates fully formed, i.e. meeting their counterparts.

The new species also possesses minute odontode-bearing platelets in the anterodorsal area of the orbit (Fig. 5). Comparisons with some other corydoradine catfishes revealed that this character may be unique to C. tukano. Interestingly, the development of small platelets in different regions of body seems to be a trend in some species of Corydoradinae, as reported in the literature (e.g. Fraser-Brunner, 1947; Britto et al., 2002).

Corydoras tukano differs from congeners with elongated dorsal fins by having a relatively short ossified portion of its dorsal spine that is similar in size in males and females. Among Corydoras, an elongated dorsal fin occurs in $C$. armatus (Günther), C. reticulatus Fraser-Brunner, C. bicolor Nijssen \& Isbrücker, $C$. ornatus Nijssen \& Isbrücker, C. paleatus (Jenyns), $C$. atropersonatus Weitzman \& Nijssen and $C$. loretoensis Nijssen \& Isbrücker (Nijssen, 1970; Britto, 1997, in press). However, in these species, the longest dorsal-fin element is the ossified portion of the dorsal spine, with its soft portion absent or reduced to a minute remnant. In addition, we found no evidence that the condition in the above cited species is related to sexual dimorphism. Elongated dorsal fins similar to that found in Corydoras tukano (i.e. on soft portion of dorsal spine and first two branched dorsal-fin rays in males) occurs in more distantly related corydoradine catfishes, such as Aspidoras virgulatus Nijssen \& Isbrücker and "Corydoras" species closer to that genus, e.g. "C." barbatus (Quoy \& Gaimard) and "C." macropterus Regan (Britto, 1997, in press). Nevertheless, the condition in these species is more extreme: the first two branched dorsal-fin rays and the soft portion of dorsal spine are twice as long, or more, than the ossified portion or the dorsal spine, while in C. tukano the elongated elements are not much longer than one-half the spine. Corydoras boehlkei Nijssen \& Isbrücker seems to be the only Corydoras that possesses a similar condition of dorsal-fin elongation to C. tukano. It is uncertain, however, if the elongation of the dorsal fin in $C$. boehlkei is a sexually dimorphic character.

Concerning the phylogenetic relationships of C. tukano, the current knowledge of the group does not allow an accurate hypothesis. Examination of characters proposed by Britto (1997, in press) tentatively places the new taxon in a small assemblage composed of $C$. trilineatus Cope, $C$. baderi Geisler, and $C$. arcuatus Elwin. However, this tentative hypothesis is weakly corroborated, because this assemblage is situated in a large polytomy with other Corydoras, and also because it is supported by highly homoplastic characters (e.g. absence of opercular odontodes), with optimizations depending on the tree topology. Color pattern characters might relate $C$. tukano to $C$. reynoldsi and $C$. weitzmani, species not examined by Britto (1997, in press). Nijssen \& Isbrücker (1980) included $C$. reynoldsi and C. weitzmani, along with some other species, in the so-called "aeneus group". However, as Nijssen \& Isbrücker (1986: 2) noticed, " [...] these groups were based on several morphometric characters and on color patterns, however, without implying a reflection of their phylogenetic relationships (which are still obscure)".

Before the 1980's, only one species of Corydoras was known from the rio Negro basin, C. melini Lönnberg \& Rendahl (1930). Since then, a host of Corydoras species have been described from the rio Negro basin in Brazil, almost all by aquarists: Corydoras adolfoi Burgess (1982), C. amandajanae Sands (1995), C. burgessi Axelrod (1987), C. crypticus Sands (1995), C. davidsandsi Black (1987), C. duplicareus Sands (1995), C. imitator Nijssen \& Isbrücker (1983b), C. incolicana Burgess (1993), C. paralellus Burgess (1993), C. nijsseni Sands (1989), C. robineae Burgess (1983), and $C$. serratus Sands (1995; see Glaser et al., 1996 for pictures of most of them). Except for $C$. robineae, all of these species possess a dark "mask", associated either with an oblique, dark bar along the dorsal region (C. adolfoi, C. davidsandsi, C. duplicareus, C. imitator, $C$. melini, and $C$. serratus), or with a dark saddle-like blotch on dorsal-fin base, extending into the dorsolateral body plates ( $C$. amandajanae, $C$. burgessi, C. crypticus, C. incolicana, C. nijsseni, and $C$. parallelus). Unlike $C$. tukano, none of them possess a "second trunk blotch" with its center at the midline of the body, or a large dark blotch at the adipose fin level. The present taxonomic status of Corydoras species from the rio Negro basin is confused, mainly because there are few specimens deposited in ichthyological collections with locality data. A proper assessment of the diversity of the genus throughout the basin requires additional sampling.

Lucanus (1998) mentioned a second "form", similar to $C$. tukano, in his words "a long snouted stretched [bodied] form". He noticed that it might represent a different species from the "short snouted high bodied form" (=C. tukano). We obtained through the courtesy of an aquarium fish exporter from Manaus a specimen of this "form" (MZUSP 82344). It represents in fact a distinct, undescribed Corydoras species, differing from $C$. tukano both in snout shape and details of color pattern. Description of this species must wait for adequate material, with precise locality data.

Corydoras tukano made its debut in the aquarium fish trade a few years ago (Anonymous, 1998; Finley, 1998; Lucanus, 1998). Judging from the amount of information on this species available on the World Wide Web (generally identified as Corydoras sp. cf. reynoldsi, Asher Cory, or Bumblebee Cory), it seems to be one of the most prized species in hobby at present. The capture of $C$. tukano in the rio Tiquié 
is done by the Tukano fishermen. They collect the fish mainly in the middle and lower portions of the river, where the species is considered to be common, and earn 150-200 Brazilian reais per one thousand specimens (about 50-67 American dollars). Corydoras species are usually only moderately abundant, and many appear to have relatively restricted distributions. Studies on the potential impacts of the aquarium trade on the natural fish populations, which are still incipient for the Amazon basin (e.g. Chao, 2001; Crampton, 1999) are clearly needed.

\section{Acknowledgements}

We are indebted to C. R. Moreira, M. Toledo-Piza, and M. Sabaj for suggestions on the manuscript. The material of the new species was collected during expeditions of the project "Peixes e pesca no alto Tiquié", a joint collaboration of MZUSP, Instituto Sociambiental (ISA), Federação das Organizações Indígenas do Rio Negro (FOIRN), and Associação das Tribos Indígenas do Alto Rio Tiquié (ATRIART). We are grateful to A. Cabalzar, M. Lopes, C.A. Ricardo, and the staff of ISA, FOIRN and ATRIART for their help and assistance. Thanks also due to the Tukano people from Caruru, for their warm hospitality, and particularly to Tarcísio, Nivaldo, Rafael, Domingos, and Feliciano, who helped during the collecting and also for sparing some edible specimens from their cooking pots. Eduardo G. Baena prepared Figs. 1 and 4. Carla Campanário prepared the map used as the basis for Fig. 6. Chihiro Yamamoto (K-2) kindly provided a specimen of the "mimic" long-snouted Corydoras. We thank D. Catania and W. Eschmeyer (CAS) for the loan of specimens. MRB received financial support from PRONEX/ CNPq (grant 300189/03-6); FCTL receives financial support from FAPESP (grant 01/14449-2).

\section{Literature Cited}

Anonymous. 1998. Neu importiert: Panzerwelse aus Brasilien. Die Aquarien und Terrarien Zeitschrifft (DATZ), 51(4):210.

Aquino, A. E. \& S. A. Schaefer. 2002. The temporal region of the cranium of loricarioid catfishes (Teleostei: Siluriformes): Morphological diversity and phylogenetic significance. Zoologischer Anzeiger, 241:223-244.

Arratia, G. \& M. Gayet. 1995. Sensory canals and related bones of tertiary siluriform crania from Bolivia and North America and comparison with recent forms. Journal of Vertebrate Paleontology, 15:482-505.

Axelrod, H. R. 1987. Two new species of catfishes (Siluriformes, Callichthyidae and Pimelodidae) from the Rio Unini, Amazonas, Brazil. Tropical Fish Hobbyist, 35:22-25.

Baskin, J. N. 1973. Structure and relationships of the Trichomycteridae. Unpublished Ph. D. Dissertation, City University of New York, New York. 389 p.

Black, B. 1987. A new species of Corydoras, Corydoras davidsandsi (Siluriformes, Callichthyidae) from the Rio Unini, Amazonas, Brazil. Practical Fishkeeping, 1987:74-75.
Britto, M. R. 1997. Filogenia da subfamília Corydoradinae (Siluriformes: Callichthyidae). Unpublished Master's Dissertation, Museu Nacional do Rio de Janeiro, Rio de Janeiro. xii+127p.

Britto, M. R. (in press). Phylogeny of the subfamily Corydoradinae Hoedeman, 1952 (Siluriformes: Callichthyidae), with a definition of its genera. Proceedings of the Academy of Natural Sciences of Philadelphia, 153.

Britto, M. R. \& R. M. C. Castro. 2002. New Corydoradine Catfish (Siluriformes: Callichthyidae) from the Upper Paraná and São Francisco: the sister group of Brochis and most of Corydoras species. Copeia, 2002:1006-1015.

Britto, M. R., F. C. T. Lima \& C. R. Moreira. 2002. Aspidoras velites, a new catfish from the upper rio Araguaia basin, Brazil (Teleostei: Siluriformes: Callichthyidae). Proceedings of the Biological Society of Washington, 115:727-736.

Burgess, W. E. 1982. Corydoras adolfoi, a new species of catfish (Siluriformes, Callichthyidae) from the upper Rio Negro, Brazil, near São Gabriel da Cachoeira. Tropical Fish Hobbyist, 30:15-16.

Burgess, W. E. 1983. Corydoras robineae, a new species of callichthyid catfish from Brazil. Tropical Fish Hobbyist, 31:42-43.

Burgess, W. E. 1989. An atlas of freshwater and marine catfishes. A preliminary survey of the Siluriformes. T.F.H. Publications, Neptune City, NJ. 784 p.

Burgess, W. E. 1993. Three new species of catfishes of the genus Corydoras (Callichthyidae: Siluriformes). Tropical Fish Hobbyist, 41:152-158.

Chao, N. L. 2001. The fishery, diversity, and conservation of ornamental fishes in the Rio Negro basin, Brazil - a review of Project Piaba (1989-1999). Pp. 161-204 In: Chao, N. L., P. Petry, G. Prang, L. Sonneschien \& M. Tlusty (eds.). Conservation and Management of Ornamental fish resources of the Rio Negro basin, Amazonia, Brazil Project Piaba, Editora da Universidade do Amazonas, Manaus.

Chernella, J. M. 1989. Managing rivers of hunger: the Tukano of Brazil. Advances in Economic Botany, 7:238-248.

Crampton, W. R. 1999. Plano de manejo para o uso sustentável de peixes ornamentais na Reserva Mamirauá. Pp. 159-176 In: Queiroz, H. L. \& W. G. R. Crampton (orgs.). Estratégias para manejo de recursos pesqueiros em Mamirauá. Sociedade Civil Mamirauá, MCT-CNPq, Brasília.

Finley, L. 1998. A couple on Corydoras. Corydoras cf. reynoldsi. Tropical Fish Hobbyist, 46:128-130.

Fraser-Brunner, F. Z. S. 1947. New fishes of the genus Corydoras. Proceedings of the Zoological Society of London, 117:241-246.

Glaser, U., F. Schäfer \& W. Glaser. 1996. All Corydoras. Verlag: A.C.S. GmbH, Germany. 142 p.

Gosline, W. A. 1940. A revision of the Neotropical catfishes of the family Callichthyidae. Stanford Ichthyological Bulletin, 2:1-29. 
James, A. 2003a. Corydoras sp. cf. reynoldsi Myers \& Weitzman, 1960. http://www.scotcat.com/factsheets/ c_cf_reynoldsi_asher.htm (updated March 2003).

James, A. 2003b. Breeding Corydoras sp. cf. reynoldsi. http:/ /corydoras.pwp.blueyonder.co.uk (updated March 2003).

Lönnberg, E. \& H. Rendahl. 1930. Eine neue Art der Gattung Corydoras. Arkiv für Zoologie, 22A:1-6.

Lucanus, O. 1998. Interesting imports. Tropical Fish Hobbyist, 47:10-11, 14.

Lundberg, J. G. 1970. The evolutionary history of North American catfishes, Family Ictaluridae. Unpublished Ph.D. Dissertation, The University of Michigan, Ann Arbor. xiii+524p.

Myers, G. S. \& S. H. Weitzman. 1960. Two new fishes collected by General Thomas D. White in eastern Colombia. Stanford Ichthyological Bulletin, 7:98-109.

Nijssen, H. 1970. Revision of the Surinam Catfishes of the genus Corydoras Lacépède, 1803 (Pisces, Siluriformes, Callichthyidae). Beaufortia, 18:1-75.

Nijssen, H. 1971. Two new species and one new subspecies of the South American catfish genus Corydoras (Pisces, Siluriformes, Callichthyidae). Beaufortia, 19:8998.

Nijssen, H. \& I. J. H. Isbrücker. 1980. A review of the genus Corydoras Lacépède, 1803 (Pisces, Siluriformes, Callichthyidae). Bijdragen tot der Dierkunde, 50:190-220.

Nijssen, H. \& I. J. H. Isbrücker. 1983a. Review of the genus Corydoras from Colombia, with descriptions of two new species (Pisces, Siluriformes, Callichthyidae). Beaufortia, 33:53-71.

Nijssen, H. \& I. J. H. Isbrücker. 1983b. Sept espèces nouvelles de Poissons-Chats cuirassés du genre Corydoras Lacepède, 1803, de Guyane française, de Bolivie, d'Argentine, du Surinam et du Brésil. Revue Française du Aquariologie et Herpetologie, 3:73-82.

Nijssen, H. \& I. J. H. Isbrücker. 1986. Review of the genus Corydoras from Peru and Ecuador (Pisces, Siluriformes, Callichthyidae). Studies on Neotropical Fauna and Environment, 21:1-68. de Pinna, M. C. C. 1998. Phylogenetic relationships of Neotropical Siluriformes (Teleostei: Ostariophysi): Historical overview and synthesis of hypothesis. Pp. 279330 In: Malabarba, L. R., R. E. Reis, R. P. Vari, Z. M. S. Lucena \& C. A. S. Lucena (Eds.). Phylogeny and classification of Neotropical fishes. Edipucrs, Porto Alegre.

Reis, R. E. 1997. Revision of the Neotropical catfish genus Hoplosternum (Ostariophysi, Siluriformes, Callichthyidae), with the description of two new genera. Ichthyological Exploration of Freshwaters, 7:299-326.

Reis, R. E. 1998. Anatomy and phylogenetic analysis of the Neotropical callichthyid catfishes (Ostariophysi, Siluriformes). Zoological Journal of the Linnean Society, 124:105-168.

Reis, R. E. 2003. Family Callichthyidae (armored catfishes). Pp. 291-309. In: Reis, R. E., S. O. Kullander \& C. J. Ferraris (Eds.). Check List of the Freshwater Fishes of South and Central America, Edipucrs, Porto Alegre.

Ribeiro, B. G. 1995. Os índios das águas pretas. EDUSP/Companhia das Letras, São Paulo. 270 p.

Sands, D. D. 1989. Mimicry unmasked. Practical Fishkeeping, 1989:44-46.

Sands, D. D. 1995. Four new Corydoras (Callichthyidae) species from Upper Negro River tributaries and a range extension, together with a discussion of $C$. bicolor Nijssen \& Isbrücker. Freshwater and Marine Aquarium, 18:8-12, $14,16,18$.

Schaefer, S. A. 1988. Homology and evolution of the opercular series in the loricarioid catfishes (Pisces: Siluroidei). Journal of Zoology, 214:81-93.

Schaefer, S. A. \& A. Aquino. 2000. Postotic laterosensory canal and pterotic branch homology in catfishes. Journal of Morphology, 246:212-227.

Taylor, W. R. \& C. C. Van Dyke. 1985. Revised procedures for staining and clearing small fishes and other vertebrates for bone and cartilage study. Cybium, 9:107-119.

Received September 22, 2003 Accepted November 21, 2003 